\title{
Mexico sets climate targets
}

But a plan to ramp up wind power could spark more conflict with indigenous groups.

\section{BY ERIK VANCE IN MEXICO CITY}

$\mathrm{F}$ aced with slow progress towards an international agreement to limit greenhousegas emissions, governments are taking the initiative by passing their own climate laws. Last week, Mexico - plagued by a persistent drought but optimistic about its prospects for wind power - made one of the boldest commitments of any nation to limit climate change. Although many countries have established domestic climate regulations, Mexico is only the second, after the United Kingdom, to make tough national targets legally binding.

Climate-policy experts say that the move sets an encouraging precedent. As a developing country with rapidly increasing emissions, "Mexico taking the lead is probably more important" than Britain doing so, says Mark Maslin of University College London, who studies climate change and its implications.

"It's at the domestic level that the rubber hits the road," says Elliot Diringer, vice-president of the Center for Climate and Energy Solutions in Arlington, Virginia. "The actions we need to see at this stage are more in the nation's capitals than in the UN negotiations."

The Mexican government has pushed for climate measures in the past, supporting efforts to develop a successor to the Kyoto Protocol, which would lock countries into an international programme of emissions reductions. And Mexico City, where transport accounts for almost half of greenhouse-gas emissions, has developed bus and subway facilities through its 2008 Green Plan to cut carbon dioxide emissions by 7 million tonnes by the end of this year.

The biggest spur to action, however, has been Mexico's current drought - the worst since records began some 70 years ago - which has ramped up public pressure on the government to take the initiative on climate change. The new law, which passed 128 to 10 in the lower house and unanimously in the Senate, mandates that $\mathrm{CO}_{2}$ emissions be reduced by $30 \%$ from business-as-usual levels by 2020 , and by $50 \%$ from 2000 levels by 2050 .

To achieve this, it demands that by 2024 , $35 \%$ of the country's electricity supply come from renewable sources, up from its current level of about $20 \%$ (see 'A mighty wind?').

\section{$\rightarrow$ NATURE.COM}

For more on troubled international climate negotiations, see: go.nature.com/c3zfk2
Mandatory emissions reporting by the country's largest greenhouse-gas producers will be overseen by a new commission, and a

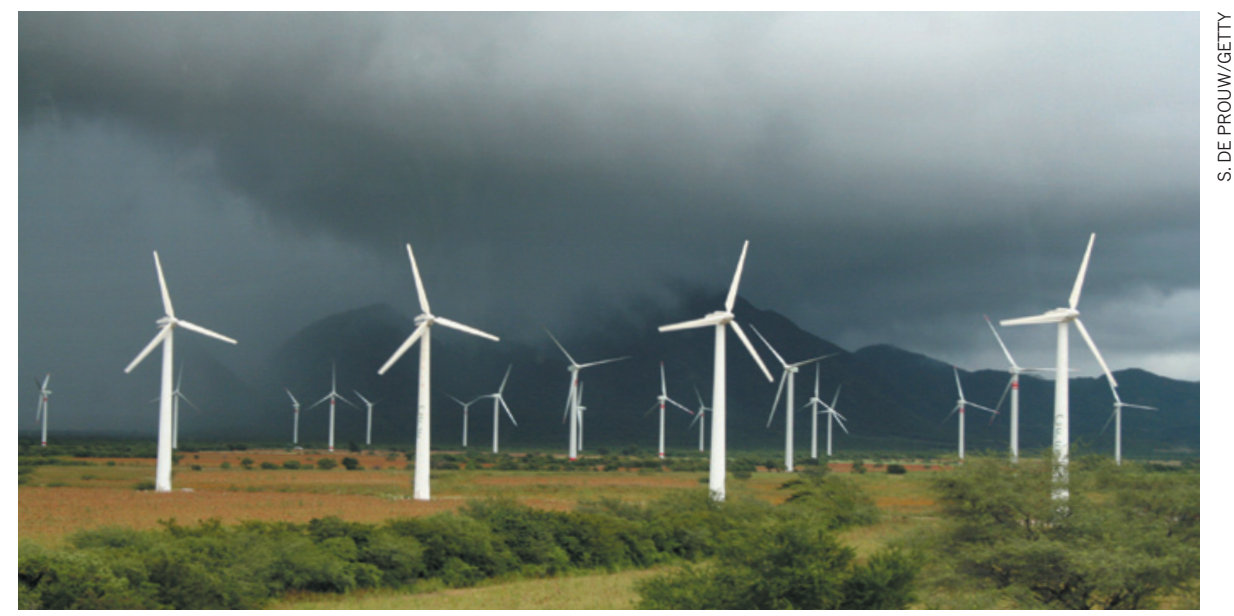

Mexico hopes to reduce its greenhouse-gas emissions by developing wind power capacity in Oaxaca.

carbon-trading scheme also looks likely.

It will be no easy task to monitor greenhousegas-intensive businesses that are thriving in the rapidly developing country. The cement industry, for example, had put up vigorous opposition to the legislation. Juan Bezaury, an expert in Mexican policy with the Nature Conservancy in Arlington, says that Mexico is "very good at making laws. The problem is enforcing them."

As with other countries that are developing national climate plans, including South Korea, Australia and South Africa, Mexico hopes to cash in on green technologies. Almost 14\% of the country's electricity comes from hydropower, but output has been hampered by the drought. Its solar-power capacity is still limited, so Mexico, much like many emerging economies, is focusing on wind power.

Mexico's government estimates that

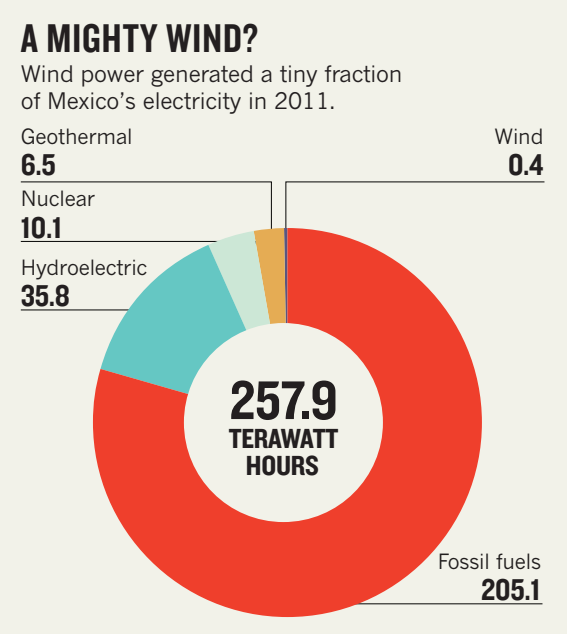

the country has the potential to generate 71 gigawatts of wind power $-40 \%$ more than its generating capacity from all energy sources, including coal and hydropower. One promising site is the Isthmus of Tehuantepec in southern Oaxaca, which is ideally placed to tap the trade winds from the Gulf of Mexico. The conditions have attracted companies to install about 2,500 megawatts of wind-power capacity in the area. But this 'wind rush' has sparked outrage from indigenous groups, who fear that their communal lands are being taken over.

"The money will always disappear, but the land will not. If we rent our land then we will lose it," says Beatriz Gutierrez Luis, a local teacher and activist in San Mateo, which last year rejected entreaties from a company to develop a wind-power station there. Protests in the area have already led to some activists being arrested, and at least one death.

"Our organization generally supports sustainable development and green energy," says Gustavo Esteva, a campaigner for indigenous peoples' rights at the Center for Intercultural Dialogues and Encounters, Oaxaca. "But it's always with the question of 'At the expense of what?"

\section{CORRECTION}

The News story 'Gene hunt is on for mental disability' (Nature 484, 302-303; 2012) incorrectly said that a rare-diseases conference was hosted by the Wellcome Trust Sanger Institute near Cambridge, UK; it was held at the Wellcome Trust Genome Campus in Hinxton. 